\title{
VITAROVAT
}

\section{Nehézfém- és egyéb toxikus mikroelem-terhelés tartamhatása a talajból mért visszanyerési százalékuk alakulására szabadföldi kísérletekben}

\author{
${ }^{1 *}$ SzABÓ Anita, ${ }^{1}$ PoKovai Klára, ${ }^{1}$ RAgÁLYi Péter, ${ }^{1}$ RÉKÁSi Márk, ${ }^{2}$ SÁNDOR Renáta, \\ ${ }^{1}$ Bernhardt Botond, ${ }^{1}$ Koncz József, ${ }^{3}$ KremPer Rita, ${ }^{1}$ CSATHó Péter \\ ${ }^{1}$ Agrártudományi Kutatóközpont, Talajtani és Agrokémiai Intézet, Budapest \\ ${ }^{2}$ Agrártudományi Kutatóközpont, Mezőgazdasági Intézet, Martonvásár \\ ${ }^{3}$ DE MÉK, Agrokémiai és Talajtani Intézet, Debrecen \\ (Beérkezett: 2019.08.07.; Elfogadva: 2019.11.19.)
}

\section{Bevezetés}

A környezeti elemek és az élővilág - föképpen lokális, pontszerü, illetve, nagyságrendekkel kisebb mértékü, diffúz - antropogén forrásból történő károsodása a kockázatelemző stratégiák folyamatos és fontos tárgya. A növényvédő szerek okozta környezeti, ill. humán egészségügyi károsodások kutatása mellett egyre nagyobb hangsúlyt kapott a nehézfémek / toxikus mikroelemek vízi, ill. szárazföldi ökoszisztémákban való viselkedésének kutatása is (ACKERFOLS, 1971). Az élelmiszerek megnövekedett nitráttartalmának egészségkárosító hatása az 1960-as években került az érdeklődés homlokterébe (SANDER \& JACOBI, 1967).

A nehézfémek, mint potenciálisan káros elemek, bizonyos koncentráció, illetve expozíciós idő / terhelés felett az emberi szervezetben súlyos egészségkárosodást okozhatnak; ezért is kiemelt fontosságú a talaj-növény-állat-(ember) táplálékláncban történő viselkedésük tanulmányozása (BERSÉNYI et al., 1999; KÁdÁR \& FEKETE, 1995; LISK, 1972; ProKISCH, 2010; SIMON, 2014; REIMANN et al., 2018).

A továbbiakban, annak értelmezési nehézségei miatt, amikor csak lehetséges, a nehézfém kifejezés helyett a káros mikroelem, illetve potenciálisan toxikus mikroelem kifejezéseket használjuk.

Az első talajvizsgálati módszereknek, mint az okszerü növénytáplálást segítő eszközök kidolgozásának „hőskora” a 19. század végére - 20. század elejére tehető.

A talaj tápelem-tartalmának meghatározásához hasonló megközelítés tapasztalható talajaink potenciálisan káros mikroelem szennyezettségének becslésére. Míg a talaj tápelem-tartalmaknál a hangsúly a kezdeti „összes” elemtartalomtól a könnyen oldható, „felvehetö” frakciót becslő, szabadföldi tartamkísérletekben kalibrált módszerekre helyeződött át, addig a legtöbb standard és humán egészségügyi talaj mikroelem-szennyezettségi határértéket ezen elemek

*Levelező szerző: SzABÓ ANITA, Agrártudományi Kutatóközpont, Talajtani és Agrokémiai Intézet, 1022 Budapest, Herman Ottó út 15.

E-mail: szabo.anita@agrar.mta.hu 
„összes” elemtartalma alapján állapították meg. A talaj „összes-” ill. „kvázi-összes” elemtartalmának becslésére számos módszer került kidolgozásra. A mikroelemek környezeti hatásait ugyanakkor inkább befolyásolja azok speciális fiziko-kémiai formája, mint az „összes” koncentrációja. Ez a felismerés vezetett a különböző kötésformákban levő mikroelemek egyedi, speciális frakcióinak meghatározására alkalmas talajvizsgálati módszerek kidolgozására (KUMPIENE et al., 2017; LAING, 2010).

A talajban lévő mikroelemek számos kémiai kötésben, ill. formációban jelenhetnek meg a talajoldatban, illetve a talaj szilárd fázisában. Legfontosabb előfordulási formái az alábbiak:

1. szabad ionok, illetve szerves, és szervetlen komplexek (a talajoldatban vannak jelen);

2. adszorbeálódott ionok, illetve vegyületek (agyag és szerves kolloidok);

3. a másodlagos ásványokba zártak, illetve az Fe- és Mn-oxidokkal csapadékot képzők (karbonátokként, foszfátokként, illetve a talajban lévő szerves anyaggal komplexet képező formációkként vannak jelen);

4. az elsődleges ásványok rácsaiba zárva jelen levők (WEST, 1981; TESSIER \& CAMPBEll, 1988; THORNTON, 1995).

A talaj „összes”, illetve „kvázi-összes” elemtartalmának meghatározására erős savas (egy vagy több sav) kioldást, illetve a hidrogén-flouridos /HF/ feltárást alkalmazzák. Ez utóbbi az egyedüli módszer, amely a szilikát-rácsokat is roncsolja. A feltárás / roncsolás gyakran magas hőmérsékleten történik. Mivel a HF feltárás igen veszélyes procedúra, ennek alternatívájaként gyakran a királyvizes roncsolást $\left(65 \mathrm{~m} / \mathrm{m} \% \mathrm{HNO}_{3}+33 \mathrm{~m} / \mathrm{m} \% \mathrm{HCl} 1: 3\right.$ arányban) használják (ISO 11466:1995). Az utóbbi a legtöbb frakcióhoz kötött potenciálisan káros mikroelemet oldja, kivéve a szilikátrácsokba épülteket. Ugyanakkor ez utóbbi módszer teljességgel alkalmas a környezetvédelmi célú vizsgálatokra, mivel valószínütlen, hogy a szilikátok kristályrácsában kötött mikroelemek valaha is a talaj mélyebb rétegébe mosódnak, avagy rövidebb, vagy akár hosszabb időtartam alatt is felvehetővé válnának a növények számára (ALLOWAY, 2013; LAING, 2010).

Hazánkban a hivatalosan elismert, a jogszabályokban (MSZ 21470-50:2006) is megjelent „kvázi-összes” (65 m/m\% $\mathrm{HNO}_{3}+30 \mathrm{~m} / \mathrm{m} \% \mathrm{H}_{2} \mathrm{O}_{2}$ oldható), a továbbiakban „,̈̈sszes”, vagy cc. $\mathrm{HNO}_{3}+$ cc. $\mathrm{H}_{2} \mathrm{O}_{2}$-oldható módszer terjedt el. Laboratóriumi összehasonlító vizsgálatok szerint a királyvíz-, valamint a cc. $\mathrm{HNO}_{3}+$ cc. $\mathrm{H}_{2} \mathrm{O}_{2}$-oldható „összes” elemtartalmak legtöbbször kevesebb, mint $\pm 10 \%$-ban különböznek egymástól (PAVLíčKOVÁ et al., 2003; ZEREMSKI-ŠKORIĆ et al., 2006).

A legáltalánosabban használt - a könnyen oldható / adszorbeált mikroelem tartalmak becslésére kidolgozott - talajvizsgálati módszerek az alábbi csoportokba sorolhatók: i) erös kelátképzö oldatok, mint EDTA, vagy DTPA; ii) nem pufferolt híg sóoldatok, mint pl. $\mathrm{CaCl}_{2}, \mathrm{MgCl}_{2}, \mathrm{NH}_{4} \mathrm{NO}_{3}, \mathrm{NaNO}_{3}, \mathrm{KNO}_{3}$; iii) gyenge szerves savak, önmagukban, vagy sav - sóoldatban, pl. ecetsav $\left(\mathrm{CH}_{3} \mathrm{COOH}\right)$, oxálsav $\left(\mathrm{H}_{2} \mathrm{C}_{2} \mathrm{O}_{4}\right)$, citromsav $\left.\mathrm{C}_{6} \mathrm{H}_{8} \mathrm{O}_{7}\right)$, ammónium-acetát $\left.\mathrm{CH}_{3} \mathrm{COONH}_{4}\right)$, nátrium-acetát $\left(\mathrm{CH}_{3} \mathrm{COONa}\right)$; iv) híg ásványisav-oldatok, pl. $\mathrm{HCl}, \mathrm{HNO}_{3}, \mathrm{HCl}+\mathrm{HNO}_{3}$ vagy $\mathrm{HCl}+\mathrm{H}_{2} \mathrm{SO}_{4}$ (Mehlich1) (HoODA, 2010). 
A hazánkban általánosan a 0,5 $\mathrm{M} \mathrm{NH}_{4}$-acetát + 0,5 M ecetsav + 0,02 M EDTA reagenst használó (a továbbiakban $\mathrm{NH}_{4}$-acetát+EDTA) Lakanen Erviö (rövidítve LE) módszer a fentiek szerint az $i$ ) csoportba sorolható (LAKANEN \& ERVIÖ, 1971). Ez, a könnyen oldható káros elemtartalmak meghatározására kidolgozott módszer a skandináv országokban és Közép-Európában terjedt el (RÉKÁSI \& FILEP, 2006). Mindezeken túl SILlanPÄÄ (1982), illetve SILLANPÄÄ \& JANSSON (1992) munkáinak köszönhetően a világ számos országának talajaira is rendelkezésre állnak ilyen jellegủ adatok.

A potenciálisan toxikus mikroelemek talajbani megkötődését, fitotoxicitását, növény általi felvehetőségét a talaj agyag- (ROSENFELS \& CRAFT, 1939) és $\mathrm{CaCO}_{3}$ tartalma (GUPTA \& GUPTA, 1998), valamint a redox viszonyok (PALMER \& PULS, 1994) is jelentősen befolyásolhatják.

Tovább árnyalja a képet, ha figyelembe vesszük a káros elemek, ill. egyes esszenciális elemek (pl. Cd-Zn; Se-S) közötti kölcsönhatásokat (antagonizmus, szinergizmus) is (MCKENNA et al., 1993; MIKKELSEN et al., 1988).

A talaj-növény rendszer potenciális toxikuselem-forgalmának megismerésében a kontrollált körülmények között folytatott, talaj- és növényvizsgálatokkal kísért szabadföldi tartamkísérletek meghatározó jelentőségüek (GYÖRI et al., 1996; JUSTE \& MENCH, 1992; KÁDÁR, 1995a, 2012a; SZABÓ et al., 2015, 2019ab).

Jelen közleményben arra a kérdésre keressük a választ, hogy a vízoldható formában, extrém nagy adagban kijuttatott potenciálisan káros mikroelemek eltérő (LE-oldható, ill. „összes”) frakcióinak talajbani felvehetősége és visszanyerési százaléka hogyan alakul a termesztett növényfaj, illetve az idő függvényében, könnyủ vályog fizikai féleségủ meszes csernozjom talajon. Röviden kitérünk az azonos körülmények között (azonos elemek, azonos kijuttatási formák és adagok, a kijuttatás óta eltelt hasonló idő), de eltérő fizikai féleségü, illetve reakcióállapotú talajokon beállított másik két hazai károselem-terheléses kísérlettel történő összehasonlító elemzésre is.

\section{Anyag és módszer}

1991 tavaszán Kádár Imre toxikus mikroelem-terheléses szabadföldi tartamkísérletet állított be munkatársaival az MTA Talajtani és Agrokémiai Kutatóintézet (ma: Agrártudományi Kutatóközpont [ATK] Talajtani és Agrokémiai Intézet [TAKI]) nagyhörcsöki kísérleti telepén, löszön képződött meszes csernozjom talajon.

A talaj szántott rétege $\mathrm{pH}_{\mathrm{KCl}}=7,8 ; \mathrm{CaCO}_{3}=6,3 \% ; \mathrm{K}_{\mathrm{A}}=38$; humusz $=3,4 \%$; hy $=2,3$; T-érték $=28$ mgeé $100 \mathrm{~g}^{-1}$ értékekkel volt jellemezhetó. A kísérlet talaja kielégítö Ca-, $\mathrm{Mg}$-, $\mathrm{Mn}$ - és $\mathrm{Cu}$-, közepes $\mathrm{N}$ - és $\mathrm{K}$-, illetve igen gyenge-gyenge $\mathrm{P}$ - és Zn-ellátottságokat mutatott (KÁDÁR, 2012a).

A toxikuselem-terheléses kísérlet 13 potenciálisan káros elem vízoldható só formájában kijuttatott $\left(\mathrm{AlCl}_{3} ; \mathrm{As}_{2} \mathrm{O}_{3} / \mathrm{NaAsO}_{2} ; \mathrm{BaCl}_{2} * 2 \mathrm{H}_{2} \mathrm{O} ; \mathrm{CdSO}_{4} * 8 / 3 \mathrm{H}_{2} \mathrm{O}\right.$; $\mathrm{K}_{2} \mathrm{CrO}_{4}, \mathrm{CuSO}_{4} * 5 \mathrm{H}_{2} \mathrm{O} ; \mathrm{HgCl}_{2},\left(\mathrm{NH}_{4}\right)_{6} \mathrm{Mo}_{7} \mathrm{O}_{24} * 4 \mathrm{H}_{2} \mathrm{O} ; \mathrm{NiSO}_{4} * 6 \mathrm{H}_{2} \mathrm{O} ; \mathrm{Pb}\left(\mathrm{NO}_{3}\right)_{2}$, $\mathrm{Na}_{2} \mathrm{SeO}_{3}, \mathrm{SrSO}_{4}$ és $\mathrm{ZnSO}_{4} * 7 \mathrm{H}_{2} \mathrm{O}$ ), 0; 90; 270 és $810 \mathrm{~kg} \mathrm{ha}^{-1}$ elemi fém (illetve 
nem-fém) mennyiségekkel, split-plot elrendezésben, két ismétlésben került beállításra, $13 \times 4 \times 2=104$ parcellán. A 13 elem sóját szilárd formában juttattuk ki. Kiszórás előtt az adott sómennyiségeket a parcella talajával 1:10 tömegarányban összekevertük az egyenletesebb kiszórás érdekében. Ez alól csupán az alumínium sója volt a kivétel, amely a kissé nyirkos talajjal elegyítve meggyulladt. Így az Al sót a lehető leggyorsabban, önmagában juttattuk ki, amely a só egyenetlen talajbeli eloszlását vonhatta maga után.

A téglalap alakú parcellák $6 \times 3,5 \mathrm{~m}$ méretúek, bruttó területük $21 \mathrm{~m}^{2}$. A parcella sorokat hosszirányban 1-1 méteres utak választják el egymástól a jobb megközelíthetöség és a talajáthordás megakadályozása érdekében.

A kísérleti növények megfelelő tápanyag-ellátottságát a kísérlet teljes időtartama alatt, évente 100-100-100 kg ha ${ }^{-1} \mathrm{~N}, \mathrm{P}_{2} \mathrm{O}_{5}$ és $\mathrm{K}_{2} \mathrm{O}$ hatóanyag-mennyiség kijuttatásával biztosítottuk, ammónium-nitrát, szuperfoszfát és $60 \mathrm{~m} / \mathrm{m} \%$-os káliumklorid formájában.

A nagyhörcsöki toxikuselem-terheléses kísérlethez hasonlóan, de 0-30-90-270 $\mathrm{kg} \mathrm{ha}^{-1}$ adagokkal és kevesebb elemmel, örbottyáni meszes homok $\left(\mathrm{pH}_{\mathrm{KCl}}=7,0\right.$; $\mathrm{CaCO}_{3}=2,5 \% ; \mathrm{K}_{\mathrm{A}}=26$; humusz $=1,3 \%$; hy = 0,6; T-érték $=11$ mgeé $\left.100 \mathrm{~g}^{-1}\right)$ és gyöngyösi savanyú kémhatású, agyagos vályog fizikai féleségü $\left(\mathrm{pH}_{\mathrm{KCl}}=5,4 ; \mathrm{y}_{1}=\right.$

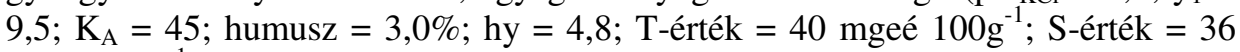
mgeé $\left.100 \mathrm{~g}^{-1} ; \mathrm{V} \%=90 \%\right)$ talajokon is állított be KÁDÁR IMRE, illetve SZABÓ LAJOS és FODOR LÁSZLÓ károselem-terheléses kísérleteket 1994 öszén, illetve 1995 tavaszán (FODOR, 2002; FODOR \& SZABÓ, 2006; KÁDÁR, 2012b) (lásd: Az eltérő fizikai féleségü, illetve reakcióállapotú talajokon beállított hazai károselemterheléses kísérletek összehasonlító elemzése c. alfejezet). Dolgozatunk többi részében kizárólag a nagyhörcsöki károselem-terheléses tartamkísérlet adatait ismertetjük.

A nagyhörcsöki tartamkísérletben kijuttatott 13 elem közül csupán a $\mathrm{Cu}$, a Zn, és a Mo tekinthető a növények számára esszenciálisnak (MORTVEDT, 1991); takarmányozási szempontból és humán vonatkozásban viszont a Se, és részben a $\mathrm{Cr}$ (III) is létfontosságú (CSATHÓ, 1994ab; HARTIKAINEN, 2005; IZSÁKI \& DEBRECZENI, 1987; KABATA-PENDIAS \& MUKHERJEE, 2007; KÁDÁR, 1998).

A talajmintákat a bruttó parcellák külső szegélye nélküli része, az ún. nettó parcellák $0-20 \mathrm{~cm}$ rétegéből, botfúróval vett $20-20 \mathrm{db}$ részminta egyesítésével képeztük.

A kísérleti eredmények kiterjeszthetőségének javítása céljából - a tartamkísérlet 4. és 18. évében (1994 és 2008) - vizsgáltuk meg az egyes elemek eltérő adagjainak a talaj könnyen oldható (LE) $\left(\mathrm{NH}_{4}\right.$-acetát+EDTA) (LAKANEN \& ERVIÖ, 1971), illetve a hazánkban hivatalosan elismert, a jogszabályokban (MSZ 21470-50:2006) is megjelent „kvázi-összes” (65 m/m\% $\mathrm{HNO}_{3}+30 \mathrm{~m} / \mathrm{m} \%$ $\mathrm{H}_{2} \mathrm{O}_{2}$ oldható, a továbbiakban „összes”, vagy cc. $\mathrm{HNO}_{3}+c c . \mathrm{H}_{2} \mathrm{O}_{2}$-oldható) elemtartalomra gyakorolt hatását. Összehasonlítottuk a két módszer eredményeit. Az elemtartalmakat ICP-OES készüléken határoztuk meg (KovÁcs et al., 2000).

A kontroll parcellák LE-oldható, ill. „összes” elemtartalmainak megállapításakor a következö alapelvet követtük: i) az 1994-es, ill. 2008-as eredményeknél KÁDÁR (2012a) közlését vettük alapul; ii) azokban az esetekben, 
amikor a kontroll kezelés esetén $<0,1 \mathrm{mg} \mathrm{kg}^{-1}$ mért értékek fordultak elő, a visszanyerési százalékok meghatározása érdekében - egységesen - a kimutathatósági határ 50\%-ának megfelelő mg kg-1 értékekkel számoltunk.

Az alumínium, mint a talajban nagy koncentrációban elöforduló elem, még a kijuttatott 90-810 $\mathrm{kg} \mathrm{ha}^{-1}$ mennyiségekben sem gyakorolt jelentős hatást a talaj LEoldható, illetve „összes” elemtartalmára, és meszes csernozjom talajunkon a növényekre sem gyakorolt fitotoxikus hatást.

Mind a LE-, mind a „összes” elemtartalmak ún. „visszanyerési százalékát” $(\mathrm{v} \%)$ is meghatároztuk annak érdekében, hogy megállapíthassuk, hogy az adott időpontban a kijuttatott káros elem hány százalékát tudtuk kimutatni a talajban az adott módszerrel.

A kijuttatott $\mathrm{kg} \mathrm{ha}^{-1}$ elem adagok $\mathrm{mg} \mathrm{kg}^{-1}$-ra való átszámításakor a térfogattömeget, illetve a szántott réteg vastagságát figyelembe véve, a konvenciónak megfelelően, a $\mathrm{kg} \mathrm{ha}^{-1}$ értékek $1 / 3$-át tekintettük az adott elem $\mathrm{mg} \mathrm{kg}{ }^{-1}$-ban kifejezett koncentrációjának.

A visszanyerési százalékot az alábbi képlettel határoztuk meg:

$$
\begin{gathered}
v \%=\frac{(E K-E \emptyset)}{\mathrm{D}} \times 100 \\
\text { ahol, } \quad \begin{array}{cl}
v \% & =\text { visszanyerési százalék } \\
E K & =\text { az adott kezelés elemtartalma, } \mathrm{mg} \mathrm{kg}^{-1} \\
E \emptyset & =\text { a kontroll kezelés elemtartalma, } \mathrm{mg} \mathrm{kg}^{-1} \\
\mathrm{D} & =\text { kijuttatott mennyiség, } \mathrm{mg} \mathrm{kg}^{-1}
\end{array}
\end{gathered}
$$

A kísérlet 1-20. évi (1991-2010) termesztett növényeinek sorrendje az alábbi volt: 1991-kukorica; 1992-sárgarépa; 1993-burgonya; 1994-borsó; 1995-cékla; 1996-spenót; 1997-búza; 1998-napraforgó; 1999-sóska; 2000-őszi árpa; 2001repce; 2002-mák; 2003-tritikálé; 2004-2008-lucerna; 2009-ugar és 2010-gyep (KÁDÁR, 2012a).

Az 1991 és 2010 közötti időszak átlagos csapadék mennyisége 522 mm, míg az 50 éves átlag ezzel gyakorlatilag megegyező, $524 \mathrm{~mm}$ volt. Csökkenő sorrendben a 2010-, 1999-, 1998-, 2005-, és a 2001-es év az átlagosnál csapadékosabb, míg - növekvő sorrendben - 1997, 2000, 1994, 2002, 2008, 2009 és 2003 az átlagosnál szárazabb volt (SZABÓ et al., 2019a).

Az 1991 és 2010 közötti időszak átlaghőmérséklete $12,0{ }^{\circ} \mathrm{C}$, míg az 50 éves átlag ennél valamivel alacsonyabb, $11,7^{\circ} \mathrm{C}$ volt. Növekvő sorrendben 1991, 1997, 2005, 2010 és 1993 az átlagosnál hidegebbnek, míg - csökkenő sorrendben - 2007, 2000, 2008, 2009, 2002, 1992, 2006 és 2003 az átlagosnál melegebbnek bizonyult.

A statisztikai kiértékeléshez a Statistica 13 (DELL, 2015) programcsomagot és a 95\%-os megbízhatósági szintet $(\mathrm{p} \leq 0,05)$ alkalmaztuk. A visszanyerési százalékok vizsgálatakor az adatok normalitását és szóráshomogenitását ellenőriztük. A szóráshomogenitás vizsgálatokhoz a Levene-tesztet, míg a normalitás vizsgálathoz a Shapiro-Wilk-tesztet használtuk. Az eredmények összevetésekor - a normalitás és a szóráshomogenitás vizsgálatot követően egytényezős variancia-analízist (ANOVA) alkalmaztunk. Nem normális eloszlás esetén Box-Cox gyökös transzformációt használtunk. Szórás inhomogenitás esetén 
- a kezelések páronkénti összehasonlításakor - Games-Howell-post hoc-tesztet futtattunk. Az ábrákon az eltérő betűk szignifikánsan eltérő mért értéket (átlagot) jelölnek.

\section{Eredmények és értékelésük}

Toxikuselem-terhelés hatása a talaj LE-oldható elemtartalmaira, valamint visszanyerési százalék értékeire meszes csernozjom talajon

A toxikuselem-terhelésnek kezelésenként, illetve a tartamkísérlet különböző éveiben a talaj LE-, illetve „összes” elemtartalmaira gyakorolt hatását KÁDÁR (2012a), illetve SZABÓ és munkatársai (2019a) közleményei ismertetik. A talaj visszanyerési százalékok meghatározásához ugyanakkor - mint ahogy az Anyag és módszer c. fejezetben szereplő képlet is mutatja -, a kontroll parcellák elemtartamának, az adott kezelés elemtartalmának, illetve a kijuttatott, $\mathrm{mg} \mathrm{kg}^{-1}$-ben kifejezett elemmennyiségek ismeretére van szükség. A talaj visszanyerési százalékok értelmezhetősége érdekében, az alábbiakban bizonyos kezelésekben és években mért, $\mathrm{mg} \mathrm{kg}^{-1}$-ban kifejezett elemtartalmait is ismertetjük.

A kontroll, illetve a legnagyobb $\left(810 \mathrm{~kg} \mathrm{ha}^{-1}\right)$ károselem-adagú kezelés LE-( $\mathrm{NH}_{4}$-acetát+EDTA) oldható elemtartalmát a kiválasztott évben és kezelésben közöljük; oldószerenként, és elemenként 3-3 adatot az alábbiak szerint: a kontroll (Ø) elemtartalmát 1994-ben, a $810 \mathrm{~kg} \mathrm{ha}^{-1}$ elemtartalmát 1994-ben és a $810 \mathrm{~kg} \mathrm{ha}^{-1}$ kezelés elemtartalmát 2008-ban. Azért választottuk a kísérlet kezdeti szakaszából a 1994. évet, mert addigra a többszöri talajmunka keverő hatása eredményeképpen a kijuttatott fémsók homogénebben oszolhattak el a szántott rétegben. Az elemek átlagában, 1991-ben és 1994-ben, gyakorlatilag azonosak voltak a LE-oldható elemtartalmak (KÁDÁR, 2012a; SZABÓ et al., 2019a).

A bemutatásra kerülő LE-oldható elemtartalmakban, abc-sorrendben, az alábbi változásokat mértük: As - Ø (1994): $0,1 \mathrm{mg} \mathrm{kg}^{-1} \rightarrow 810 \mathrm{~kg} \mathrm{ha}^{-1}$ (1994): $80 \mathrm{mg} \mathrm{kg}^{-1}$ $\rightarrow 810 \mathrm{~kg} \mathrm{ha}^{-1}$ (2008): $24 \mathrm{mg} \mathrm{kg}{ }^{-1} ; \mathrm{Ba}-18 \rightarrow 67 \rightarrow 69 ; \mathrm{Cd}-0,01 \rightarrow 164 \rightarrow 113$; $\mathrm{Cr}-0,02 \rightarrow 4 \rightarrow 1,5 ; \mathrm{Cu}-4 \rightarrow 192 \rightarrow 105 ; \mathrm{Hg}-0,03 \rightarrow 41 \rightarrow 0,8 ; \mathrm{Mo}-0,01 \rightarrow$ $25 \rightarrow 30 ; \mathrm{Ni}-4 \rightarrow 86 \rightarrow 55 ; \mathrm{Pb}-5 \rightarrow 260 \rightarrow 99 ; \mathrm{Se}-0,12 \rightarrow 89 \rightarrow 1,9 ; \mathrm{Sr}-40$ $\rightarrow 314 \rightarrow 110 ; \mathrm{Zn}-\varnothing$ (1994): $1 \mathrm{mg} \mathrm{kg}{ }^{-1} \rightarrow 810 \mathrm{~kg} \mathrm{ha}^{-1}(1994): 147 \mathrm{mg} \mathrm{kg}^{-1} \rightarrow 810$ $\mathrm{kg} \mathrm{ha}^{-1}$ (2008): $59 \mathrm{mg} \mathrm{kg}^{-1}$ (KÁDÁR, 2012a; SZABÓ et al., 2019a).

1994-ben a kontroll kezelésekben a LE-oldható elemtartalom a $\mathrm{Sr}>\mathrm{Ba}>\mathrm{Pb}>$ $\mathrm{Cu}=\mathrm{Ni}>\mathrm{Zn}>\mathrm{Se}>\mathrm{As}>\mathrm{Hg}>\mathrm{Cr}>\mathrm{Cd}=$ Mo sorrendben csökkent. A kontroll kezelésekben a talajok LE-oldható elemtartalom sorrendje jó egyezőséget mutat a hasonló hazai és nemzetközi adatokkal (BOLDIS, 1994; LEHOCZKY et al., 1998; SILLANPÄÄ \& JANSSON, 1992).

A legnagyobb adagú $\left(810 \mathrm{~kg} \mathrm{ha}^{-1}\right)$ kezelésben 1994 és 2008 között a LE-oldható tartalmakban a legnagyobb csökkenéseket a Sr, Pb és Zn (204; 161; 88 $\left.\mathrm{mg} \mathrm{kg}^{-1}\right)$, a legkisebbeket pedig a Mo, Ba és $\mathrm{Cr}\left(-5 ;-2 ;-3 \mathrm{mg} \mathrm{kg}^{-1}\right)$ elemek mutattak (KÁDÁR, 2012a; SZABÓ et al., 2019a). 
A 90-270-810 $\mathrm{kg} \mathrm{ha}^{-1}$ adagoknak a két időpontban a LE-oldható elemtartalomra gyakorolt hatását közvetve, visszanyerési százalékuk (v\%) ismertetésével mutatjuk be, elemenként a három adag átlagában (1. ábra).

Dolgozatunkban a LE-oldható elemtartalmak 4. és 18. évi visszanyerési százalékát mutatjuk be. Az elemek sorrendjét az 1994. évi eredmények alapján állapítottuk meg.

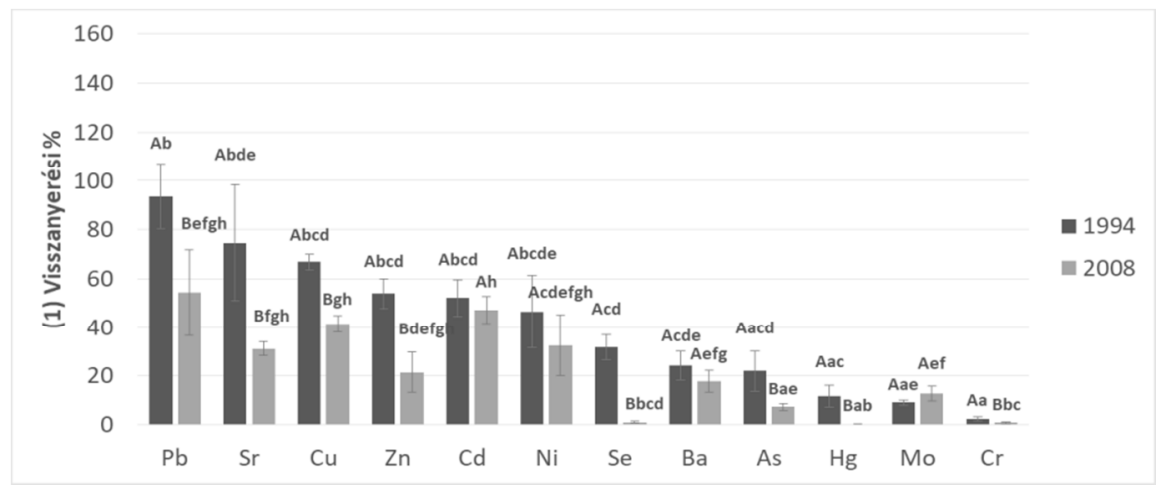

\section{1. ábra}

A potenciálisan káros elemek 1994. és 2008. években mért LE-oldható elemtartalom visszanyerési százalékai a szántott rétegben. Meszes csernozjom, Nagyhörcsök. A kisbetük éven belüli; a nagybetük évek közötti szignifikáns különbségeket jelölnek

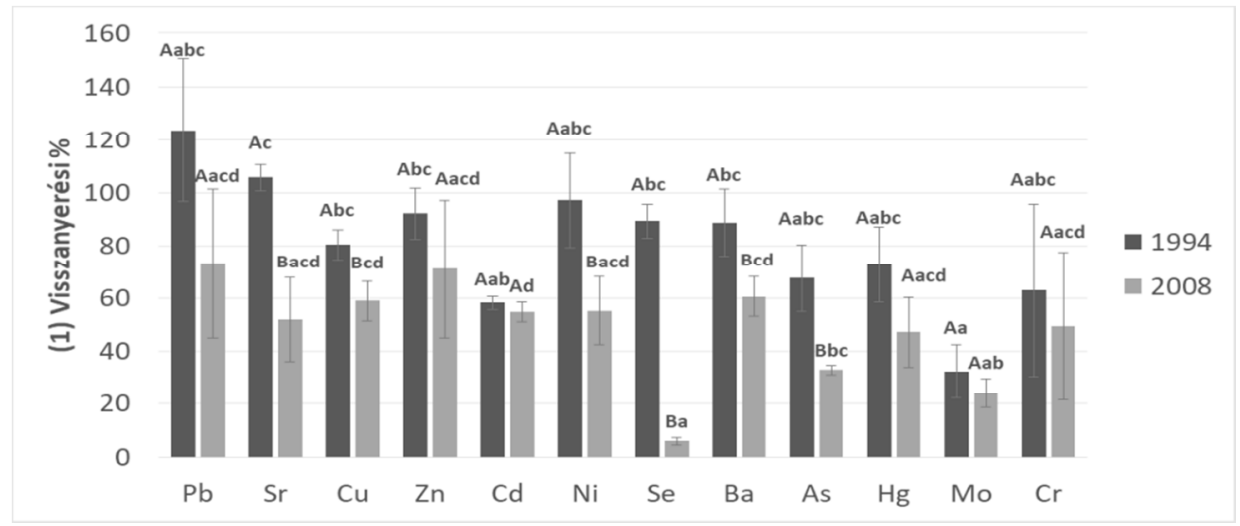

2. ábra

A potenciálisan káros elemek 1994. és 2008. években mért „összes” elemtartalom visszanyerési százalékai a szántott rétegben. Meszes csernozjom, Nagyhörcsök. A kisbetűk éven belüli; a nagybetük évek közötti szignifikáns különbségeket jelölnek 
Az egyes elemek LE-oldható elemtartalom szerinti visszanyerési százalékában igen nagy különbségek alakultak ki $(1994: \mathrm{Pb}-94 \%>\mathrm{Sr}-75 \%>\mathrm{Cu}-67 \%>\mathrm{Zn}$ $-54 \%>\mathrm{Cd}-52 \%>\mathrm{Ni}-46 \%>\mathrm{Se}-32 \%>\mathrm{Ba}-24 \%>\mathrm{As}-22 \%>\mathrm{Hg}-12 \%>$ Mo $-9 \%$, illetve $\mathrm{Cr}-2 \%$; 2008: $\mathrm{Pb}-54 \%,>\mathrm{Cd}-47 \% ; \mathrm{Cu}-41 \%>\mathrm{Ni}-33 \%>$ $\mathrm{Sr}-31 \%>\mathrm{Zn}-21 \%>\mathrm{Ba}-18 \%>\mathrm{Mo}-13 \%>\mathrm{As}-7 \%>\mathrm{Se}-1 \%>\mathrm{Cr}-0,8 \%$, illetve $\mathrm{Hg}-0,1 \%$ ) (1. ábra).

Az egyes elemeknél feltüntetett szórás értékek a 3 kijuttatási szint, a 90, a 270, illetve a $810 \mathrm{~kg} \mathrm{ha}^{-1}$ adagok visszanyerési százalékának szórására utalnak. Általában azoknál az elemeknél volt nagyobb a szórás, amely elemek kontroll parcelláin a legnagyobb LE-oldható elemtartalmakat mértük.

Nagyobb visszanyerési százalékokat kaptunk a kationos formában kiadott elemek esetében, míg az anionos formában kijuttatottak (Se, As, Mo, Cr) az elemsorrend második felében, illetve a végén helyezkedtek el (2. ábra). Az anionos elemek a kísérleti talajunkhoz hasonló, alkalikus közegben oldékonyabbak (mindezeken túl, az agyagásványokon is kisebb mértékben kötődnek meg, mint a kationok), így fitotoxikus hatásuk, és felvehetőségük, illetve a talaj mélyebb rétegeibe való kimosódásuk ( $\mathrm{pl}$. Se, $\mathrm{Cr}$ ) is ezeken a talajokon lehet a legerőteljesebb (KÁDÁR, 2012a). A Cr fitotoxicitása, illetve oldhatósága vegyérték-váltása következtében is jelentősen változhat. A $\mathrm{Cr}(\mathrm{VI})$ például, a nitráthoz hasonlóan, kimosódásra hajlamos. A fémek közül a $\mathrm{Hg}$ - a többi nehézfémtől eltéröen - igen kis visszanyerési százalékokat mutatott. Ennek oka egyfelől az lehetett, hogy a $\mathrm{Hg}$ szublimációra hajlamos elem, másrészt, a legtöbb anionnal, így pl. a kloriddal is, oldhatatlan vegyületet alkot a talajban. A Hg-szublimációhoz hasonló jelenség játszódhatott le a kísérlet Se-kezeléses parcelláin is, amelyeken sajátos, a fokhagymára emlékezető ,illat” volt érezhető. Mint ismeretes, a szelén a kénhez áll kémiailag legközelebb, a fokhagyma illatot pedig az allil-szulfidok képezik. A Se egy része valamilyen szerves Se-származék formájában illanhatott el a talajból. Az esszenciális, anionos formában kijuttatott Se és Mo elemeket a többi elemnél nagyságrenddel nagyobb mennyiségben vették fel a növények, ezzel is hozzájárulva a visszanyerési százalékértékek csökkenéséhez (KÁDÁR, 2012a).

A két mintavétel, illetve analízis között 14 év telt el. Ez alatt az idő alatt a legtöbb elem LE-módszer szerint kimutatott oldhatósága, és így visszanyerési százaléka kisebb-nagyobb mértékben csökkent. Legnagyobb csökkenést a $\mathrm{Sr}, \mathrm{Pb}$, Zn, míg legkisebbet a Mo, Cr és Cd elemek mutatták. A tápláléklánc szennyezödése szempontjából kedvezőtlen, hogy a kijuttatott karcinogén $\mathrm{Cd}$ jelentős hányada maradt a könnyen oldható frakcióban, és ez a frakció a 14 év alatt is csak minimálisan csökkent a meszes csernozjom talajunkon (1. ábra).

A kadmium növény általi erőteljes felvehetőségét 25 potenciális káros elemmel beállított tenyészedény kísérlet eredményei is megerősítették; a legnagyobb mértékü talaj => növény transzfert éppen a kadmium mutatott (ENAMORADO et al., 2014).

$\mathrm{Az}$ elemek átlagában, a LE-oldható elemtartalomban mért visszanyerési százalék 1994-ben 41\%, míg 2008-ban 22\% volt. A 14 év alatt tehát az átlagos, LEoldható elemtartalomban mért visszanyerési százalék 19 abszolút \%-kal csökkent, azaz, gyakorlatilag megfeleződött. 
A LE-módszer szerint kimutatott elemtartalmak, illetve visszanyerési százalékok tehát a kijuttatott elemek kémiai sajátosságai és adagjai, a kísérleti talaj tulajdonságai (pl. pH, mésztartalom, fizikai féleség, talaj szervesanyag-tartalom), a talajmintavételi hiba, a tesztnövény (fitotoxikusság, illetve elemfelvétel mértéke), és a kijuttatás óta eltelt idő függvényében számottevő mértékben változhatnak. A LEkivonószer jelentős arányban viheti talajoldatba az antropogén eredetủ károselemfrakciókat a talajból (BOLDIS, 1994; SILLANPÄÄ \& JANSSON, 1992; KÁDÁR, 1995b; VÁRALlyAY, 1995) (1. ábra).

Toxikuselem-terhelés hatása a talaj „összes” elemtartalmára, valamint visszanyerési százalék értékeire meszes csernozjom talajon

A kontroll, illetve a legnagyobb $\left(810 \mathrm{~kg} \mathrm{ha}^{-1}\right)$ adagú talajkezelés „összes” (cc. $\mathrm{HNO}_{3}+\mathrm{cc} . \mathrm{H}_{2} \mathrm{O}_{2}$-oldható) elemtartalmait a kiválasztott évben és kezelésben közöljük; oldószerenként, és elemenként 3-3 adatot az alábbiak szerint; a kontroll elemtartalmát 1994-ben, a $810 \mathrm{~kg} \mathrm{ha}^{-1}$ elemtartalmát 1994-ben és a $810 \mathrm{~kg} \mathrm{ha}^{-1}$ elemtartalmát 2008-ban.

A bemutatásra kerülő „összes” elemtartalmakban, abc-sorrendben, az alábbi változásokat mértünk: As - Ø (1994): $12 \mathrm{mg} \mathrm{kg}^{-1} \rightarrow 810 \mathrm{~kg} \mathrm{ha}^{-1}$ (1994): $210 \mathrm{mg} \mathrm{kg}$ ${ }^{1} \rightarrow 810 \mathrm{~kg} \mathrm{ha}^{-1}$ (2008): $105 \mathrm{mg} \mathrm{kg}^{-1} ; \mathrm{Ba}-80 \rightarrow 298 \rightarrow 253 ; \mathrm{Cd}-0,1 \rightarrow 162 \rightarrow$ $142 ; \mathrm{Cr}-18 \rightarrow 121 \rightarrow 92 ; \mathrm{Cu}-17 \rightarrow 230 \rightarrow 152 ; \mathrm{Hg}-0,1 \rightarrow 157 \rightarrow 87$; $\mathrm{Mo}-$ $0,1 \rightarrow 114 \rightarrow 80 ; \mathrm{Ni}-28 \rightarrow 248 \rightarrow 142 ; \mathrm{Pb}-10 \rightarrow 264 \rightarrow 126 ; \mathrm{Se}-0,3 \rightarrow 224$ $\rightarrow 13 ; \mathrm{Sr}-60 \rightarrow 352 \rightarrow 176 ; \mathrm{Zn}-\varnothing(1994): 40 \mathrm{mg} \mathrm{kg}^{-1} \rightarrow 810 \mathrm{~kg} \mathrm{ha}^{-1}$ (1994): $274 \mathrm{mg} \mathrm{kg}^{-1} \rightarrow 810 \mathrm{~kg} \mathrm{ha}^{-1}$ (2008): $174 \mathrm{mg} \mathrm{kg}^{-1}$ (KÁDÁR, 2012a).

1994-ben a kontroll kezelésekben az „összes” elemtartalmak az alábbi sorrendben csökkentek: $\mathrm{Ba}>\mathrm{Sr}>\mathrm{Zn}>\mathrm{Ni}>\mathrm{Cr}>\mathrm{Cu}>\mathrm{As}>\mathrm{Pb}>\mathrm{Se}>\mathrm{Cd}=\mathrm{Hg}=$ Mo. A kontroll kezelések „összes” elemtartalmainak a sorrendje szintén jó egyezőséget mutat a hazai- és nemzetközi irodalmi adatokkal (KABATA-PENDIAS, 2011; KÁDÁR, 2009; LISK, 1972; NÉMETH et al., 1997; SCHACKLETTE \& BOERNGEN, 1984). A talajok természetes potenciálisan káros mikroelem-tartalma a talaj agyagtartalma függvényében növekedhet (BOLDIS, 1994; KÁDÁR, 2009). A nagyobb agyagtartalmú talajok nagyobb pufferkapacitása következtében ugyanakkor ez nem jelenti azt, hogy az ezen a talajon fejlödött növények toxikuselem-felvétele is megnövekszik (ROSENFELS \& CRAFT, 1939). A vályog fizikai féleségü talajunk átlagos toxikuselem háttérszennyezettséget mutatott (KÁDÁR, 2009).

A szántott rétegben az „összes” elemtartalmakban a $810 \mathrm{~kg} \mathrm{ha}^{-1}$ kezelésben 1994 és 2008 között a legnagyobb csökkenéseket a Se, Sr és $\mathrm{Pb}(211 ; 176$; $\left.138 \mathrm{mg} \mathrm{kg}^{-1}\right)$, a legkisebbeket a Cd, Cr és Mo (20;29; $\left.34 \mathrm{mg} \mathrm{kg}^{-1}\right)$ elemek mutattak.

A kationos, ill. anionos formában kijuttatott potenciálisan toxikus mikroelemeknek a talajok fizikai és kémiai tulajdonságai függvényében történő adszorpciós sorendjéről, megkötődésének erősségéről KORTE és munkatársai (1976) közöltek eredményeket. Természetesen, a fenti toxikus mikroelemek megkötődési sorrendjét jelentősen befolyásolhatják az adott kivonószer kémiai tulajdonságai. 
A 90-270-810 kg ha-1 adagoknak az „összes” elemtartalomra gyakorolt hatását közvetve, visszanyerési százalékuk ismertetésével mutatjuk be, elemenként a három adag átlagában.

A talaj „összes” elemtartalmának a 4. és a 18. évi visszanyerési százalékát a 2. ábra ismerteti. Az elemek sorrendjét az 1994. évi LE-eredmények alapján állapítottuk meg. Azért választottuk az 1994. évi LE szerinti elemsorrendet, mivel a későbbiekben a két kivonószernél kapott visszanyerési százalékok egymáshoz viszonyított arányát is meghatározzuk (1. és 2. ábrák, 1. táblázat).

A két időpontban az egyes elemek az „összes” elemtartalomban mért visszanyerési százalékuk mértékében, illetve sorrendjében is különbözőséget mutattak $(1994 \mathrm{~Pb}-124 \%>\mathrm{Sr}-106 \%>\mathrm{Ni}-97 \%>\mathrm{Zn}-92 \%>\mathrm{Ba}=\mathrm{Se}-89 \%$ $>\mathrm{Cu}-80 \%>\mathrm{Hg}-73 \%>\mathrm{As}-68 \%>\mathrm{Cr}-63 \%>\mathrm{Cd}-58 \%>\mathrm{Mo}-32 \% ; 2008$ : $\mathrm{Pb}-73 \%>\mathrm{Zn}-71 \%>\mathrm{Ba}-61 \%>\mathrm{Cu}-59 \%>\mathrm{Cd}=\mathrm{Ni}-55 \%>\mathrm{Sr}-52 \%>\mathrm{Cr}-$ $50 \%>\mathrm{Hg}-47 \%>\mathrm{As}-33 \%>\mathrm{Mo}-24 \%>\mathrm{Se}-6 \%$ ) (2. ábra).

Értelemszerüen, az „összes” elemtartalomra vonatkozó visszanyerési százalékok jóval nagyobb értékeket mutattak, mint a LE-oldható elemtartalmaké.

Az egyes elemek „összes” elemtartalomban kifejezett visszanyerési százalékának szórása a LE-oldható tartalomnál leírt tendenciát követte.

Az egyes elemek „összes” elemtartalomban 1994-ben mért visszanyerési százalékának sorrendje a LE-oldható tartalmaknál leírtakhoz hasonlóan alakult; a legkisebb visszanyerési százalékokat itt is az anionos formában kijuttatott elemek esetén kaptunk. Míg a LE-oldható tartalmaknál a $\mathrm{Hg}$, addig az „összes” elemtartalmaknál a $\mathrm{Cd}$, mint nehézfém ékelödött be az anion formában kijuttatott elemek közé.

Az „összes” elemtartalomban mért visszanyerési százalékokban a legnagyobb csökkenéseket a $\mathrm{Se}, \mathrm{Sr}, \mathrm{Pb}$, míg legkisebbeket a $\mathrm{Cd}$, Mo és $\mathrm{Cr}$ elemek mutattak (2. ábra). Az utóbbi három elem közül humán egészségügyi szempontból a $\mathrm{Cd}$ tekinthető a legveszélyesebbnek.

Az elemek átlagában, az összes elemtartalomban mért visszanyerési százalék 1994-ben 81\%, míg 2008-ban 49\% volt. A 14 év alatt tehát az átlagos összes elemtartalomban mért visszanyerési százalék 32 abszolút \%-kal csökkent.

Az „összes” elemtartalmak, illetve visszanyerési százalékok, hasonlóan a LE-oldható elemtartalmakhoz, a kijuttatott elemek kémiai sajátosságai és adagjai, a kísérleti talaj tulajdonságai (pl. pH, mésztartalom, fizikai féleség, talaj szervesanyag-tartalom), a talajmintavételi hiba, a tesztnövény (fitotoxikusság, illetve elemfelvétel mértéke), a kijuttatás óta eltelt idő függvényében jelentősen változhatnak (DEBRECZENI \& IZSÁKI, 1989; KIRBY et al., 2012; KUMPIENE et al., 2017; LOCK et al., 2006; LU et al., 2009; MA et al., 2013) (2. ábra). 
Nehézfémterhelés hatása ... visszanyerési százalékuk alakulására... 303

A visszanyerési százalékok egymáshoz viszonyított arányai a kivonószer, illetve az idö függvényében meszes csernozjom talajon

A visszanyerési százalékok egymáshoz viszonyított arányait a kivonószer, illetve az idő függvényében is kifejeztük (1. táblázat).

1994-hez képest 2008-ban - 14 év elteltével - a LE-kivonószerben kifejezett visszanyerési százalékok az alábbi sorrendben mérséklődtek: $\mathrm{Cd}>\mathrm{Mo}>\mathrm{Ba}>\mathrm{Ni}>$ $\mathrm{Cu}>\mathrm{Pb}>\mathrm{Sr}>\mathrm{Zn}>\mathrm{Cr}>\mathrm{As}>\mathrm{Se}>\mathrm{Hg}$. Az elemek átlagában tehát 2008-ban az 1994-ben mért LE visszanyerési százalékoknak már csupán mintegy 50\%-át tudtuk kimutatni.

Ugyanezen 14 éves időszak elteltével az „összes” elemtartalomban kifejezett visszanyerési százalékok az alábbi sorrendben mérséklődtek: $\mathrm{Cd}>\mathrm{Cr}>\mathrm{Zn}>\mathrm{Mo}>$ $\mathrm{Cu}>\mathrm{Ba}>\mathrm{Hg}>\mathrm{Pb}>\mathrm{Ni}>\mathrm{Sr}>\mathrm{As}>\mathrm{Se}$. Az elemek átlagában 2008-ban az 1994ben mért „összes” visszanyerési százaléknak valamivel több mint 60\%-át tudtuk kimutatni.

\section{1. táblázat}

A visszanyerési százalékok egymáshoz viszonyított arányai a kivonószer, illetve az idő függvényében. Meszes csernozjom, Nagyhörcsök, 1994 és 2008

\begin{tabular}{|c|c|c|c|c|}
\hline (1) Elemek & $\begin{array}{c}\text { (2) LE } \\
2008 / 1994(\%)\end{array}$ & $\begin{array}{c}\text { (3) „Összes” } \\
\text { 2008/1994 (\%) }\end{array}$ & $\begin{array}{c}\text { (4) LE / "Összes" } \\
1994(\%)\end{array}$ & $\begin{array}{c}\text { (5) LE / "Összes" } \\
2008(\%)\end{array}$ \\
\hline \multicolumn{5}{|c|}{ (6) Visszanyerési \% } \\
\hline As & 33 & 49 & 32 & 22 \\
\hline $\mathrm{Ba}$ & 74 & 68 & 27 & 29 \\
\hline $\mathrm{Cd}$ & 90 & 94 & 89 & 86 \\
\hline $\mathrm{Cr}$ & 33 & 78 & 4 & 2 \\
\hline $\mathrm{Cu}$ & 62 & 73 & 83 & 70 \\
\hline $\mathrm{Hg}$ & 1 & 65 & 16 & 0 \\
\hline Mo & 78 & 75 & 28 & 29 \\
\hline $\mathrm{Ni}$ & 70 & 57 & 48 & 59 \\
\hline $\mathrm{Pb}$ & 58 & 59 & 76 & 74 \\
\hline $\mathrm{Se}$ & 3 & 7 & 36 & 16 \\
\hline $\mathrm{Sr}$ & 42 & 49 & 71 & 60 \\
\hline $\mathrm{Zn}$ & 40 & 77 & 59 & 30 \\
\hline (7) Átlag & 49 & 63 & 47 & 40 \\
\hline
\end{tabular}

A LE- kivonószerben mért visszanyerési százalékok és a cc. $\mathrm{HNO}_{3}+c c \cdot \mathrm{H}_{2} \mathrm{O}_{2}$ kivonószerben mért „összes” visszanyerési százalékok egymáshoz viszonyított arányát is meghatároztuk mind a két időpontban, 1994-ben és 2008-ban is. Fontos jövőbeni kutatási terület lehet annak megállapítása, hogy az egyes elemeknek az időben változó LE visszanyerési százalékai / "összes" visszanyerési százalékai egymáshoz viszonyított arányának változásaiból visszakövetkeztethetünk-e az adott elem korábbi, (víz-) oldható formában történt szennyezésének korára (1. táblázat).

Ebben az összehasonlításban, 1994-ben, a LE visszanyerési százalék / "összes" visszanyerési százalék elemarányai $\mathrm{Cd}>\mathrm{Cu}>\mathrm{Pb}>\mathrm{Sr}>\mathrm{Zn}>\mathrm{Ni}>\mathrm{Se}>\mathrm{As}>\mathrm{Mo}>$ 
Ba $>\mathrm{Hg}>\mathrm{Cr}$; míg 2008-ban $\mathrm{Cd}>\mathrm{Pb}>\mathrm{Cu}>\mathrm{Sr}>\mathrm{Ni}>\mathrm{Zn}>\mathrm{Ba}>\mathrm{Mo}>\mathrm{As}>\mathrm{Se}>$ $\mathrm{Cr}>\mathrm{Hg}$ sorrendben csökkentek.

Az eltérö fizikai féleségü, illetve reakcióállapotú talajokon beállított hazai károselem-terheléses kísérletek összehasonlító elemzése

A nagyhörcsöki toxikus mikroelem-terheléses kísérlethez hasonlóan, azzal azonos só formákban, de csupán a 0-30-90-270 $\mathrm{kg} \mathrm{ha}^{-1}$ adagokkal és kevesebb elemmel, őrbottyáni meszes homok és gyöngyösi savanyú agyagos vályog talajokon is állított be KÁDÁR (2012b) és FODOR (2002); valamint FODOR \& SZABÓ (2006) károselem-terheléses kísérleteket 1994 öszén, illetve 1995 tavaszán.

FODOR \& SZABÓ (2006) közleményükben megadták mind a LE-oldható, mind az „összes” elemtartalmak visszanyerési százalékait is (2. táblázat 4. és 8. oszlopok). A Pb elemet - nagy szórása miatt - kihagytuk az értékelésböl.

\section{2. táblázat}

A potenciálisan káros elemek LE-oldható, illetve „összes” elemtartalom visszanyerési százalékai, valamint azok egymáshoz viszonyított arányai a három kísérleti helyen beállított károselem-terheléses kísérlet szántott rétegében, a $270 \mathrm{~kg} \mathrm{ha}^{-1}$ kezelésben

\begin{tabular}{|c|c|c|c|c|c|c|c|c|c|c|c|c|}
\hline \multirow{2}{*}{ (1) Elem } & \multicolumn{4}{|c|}{ (2) LE visszanyerési \% } & \multicolumn{4}{|c|}{ (3) "összes" visszanyerési \% } & \multicolumn{4}{|c|}{$\begin{array}{l}\text { (4) (LE visszanyerési \%) /("összes" } \\
\text { visszanyerési \%) arány, \% }\end{array}$} \\
\hline & $\begin{array}{l}\text { (5) ÖB } \\
\text { (6.év) }\end{array}$ & $\begin{array}{l}\text { (6) } \mathrm{NH} \\
\text { (4. év) }\end{array}$ & \begin{tabular}{|c|} 
(7) GYÖ \\
(2. év)
\end{tabular} & (8) Átlag & $\begin{array}{l}\text { (5) ÖB } \\
\text { (6.év) }\end{array}$ & $\begin{array}{l}\text { (6) } \mathrm{NH} \\
\text { (4. év) }\end{array}$ & $\begin{array}{c}\text { (7) GYÖ } \\
\text { (2. év) }\end{array}$ & (8) Átlag & $\begin{array}{l}\text { (5) ÖB } \\
\text { (6.év) }\end{array}$ & $\begin{array}{l}\text { (6) } \mathrm{NH} \\
\text { (4. év) }\end{array}$ & $\begin{array}{c}\text { (7) GYö } \\
\text { (2. év) }\end{array}$ & (8) Átlag \\
\hline As & & 23 & 22 & 23 & & 77 & 73 & 75 & - & 32 & 30 & 31 \\
\hline $\mathrm{Cd}$ & - & 49 & 85 & 67 & - & 55 & 99 & 77 & - & 89 & 86 & 88 \\
\hline $\mathrm{Cr}$ & 1 & 2 & 2 & 2 & 87 & 51 & 79 & 72 & 2 & 4 & 2 & 3 \\
\hline $\mathrm{Cu}$ & 35 & 68 & 48 & 50 & 50 & 76 & 63 & 63 & 70 & 83 & 76 & 76 \\
\hline $\mathrm{Hg}$ & -1 & 13 & 4 & 9 & - & 74 & 43 & 59 & -1 & 16 & 9 & 13 \\
\hline $\mathrm{Se}$ & 3 & 37 & -1 & 20 & 11 & 90 & -1 & 50 & 27 & 36 & -1 & 32 \\
\hline $\mathrm{Zn}$ & 16 & 48 & 43 & 36 & 44 & 87 & 72 & 68 & 36 & 59 & 60 & 52 \\
\hline (8) Átlag (ÖB-NH-GYÖ) & 17 & 39 & 31 & 29 & 60 & 71 & 71 & 68 & 36 & 48 & 46 & 43 \\
\hline (8) Átlag (ÖB-NH) & 14 & 39 & - & 26 & 48 & 76 & - & 62 & 34 & 45 & 7 & 40 \\
\hline (8) Átlag (NH-GYÖ) & -1 & 34 & 34 & 34 & & 70 & 72 & 71 & & 47 & 44 & 46 \\
\hline
\end{tabular}

ÖB = Örbottyán, NH = Nagyhörcsök, GYÖ = Gyöngyös

A három helyszín $270 \mathrm{~kg} \mathrm{ha}^{-1}$-os adagjához kötődő LE visszanyerési százalék / "összes" visszanyerési százalék arányait a 2 . táblázat tartalmazza.

A három talaj $270 \mathrm{~kg} \mathrm{ha}^{-1}$ kezelés között a következő eltéréseket tapasztaltuk:

- Az „összes” visszanyerési \%-ok az elemek átlagában savanyú agyagos vályog talajon a 2. évben és meszes vályogtalajon a 4. évben gyakorlatilag azonosak voltak.

- Ugyanez mondható el a 2. illetve 4. évi LE visszanyerési \%-okra, illetve a 2. és 4. évi LE visszanyerési \% / "összes" visszanyerési \% arányokra.

- Az „összes” visszanyerési \%-ok vonatkozásában savanyú agyagos vályog talajon a 2. évben jelentösen nagyobb volt a $\mathrm{Cd}$, és a $\mathrm{Cr}$,összes" visszanyerési \%-a, mint meszes vályogtalajon a 4. évben. Ezzel ellentétben a Hg meszes vályogtalajon még a 4. évben is majdnem kétszer akkora „összes” visszanyerési \%-ot mutatott, mint savanyú agyagos vályog talajon a 2. évben. 
- A könnyen oldható visszanyerési \%-ok is az „összes” visszanyerési \%-okhoz hasonló tendenciákat mutattak. Ez alól csak a Cr volt kivétel, amely nem csak savanyú agyagos vályog talajon és meszes vályog talajon, de meszes homoktalajon is minimálisra csökkent a 2-4-6. évre.

- A LE / "összes" visszanyerési \% arányok savanyú agyagos vályog talajon a 2. évben gyakorlatilag azonos értékeket mutattak a meszes vályogtalaj 4. évi adataival. Ez alól talán csak a $\mathrm{Hg}$ tekinthető kivételnek, amely meszes vályog talajon a 4 . évben több mint 50\%-kal nagyobb volt, mint savanyú agyagos vályog talajon a 2 . évben.

Úgy találtuk, hogy indokolt lehet a 4. évi nagyhörcsöki kísérlet 90-270-810 kg ha $^{-1}$ adagjai átlagában közölt LE visszanyerési százalék / "összes" visszanyerési százalék arányok (1. táblázat), valamint három helyszín $270 \mathrm{~kg} \mathrm{ha}^{-1}$ kezelésekhez kötődő (Gyöngyös: 2. évi, Nagyhörcsök: 4. évi és Örbottyán: 6. évi) LE visszanyerési százalék / "összes" visszanyerési százalék arányok (2. táblázat) összehasonlítása, különös tekintettel azok elemsorrendjére. Ennek érdekében, a 3. táblázatban megadtuk a $270 \mathrm{~kg} \mathrm{ha}^{-1}$ adaghoz kötődő LE / "összes" visszanyerési százalék arányok elemsorrendjét.

A nagyhörcsöki kísérlet három kezelésének átlagában, illetve a három kísérleti hely $270 \mathrm{~kg} \mathrm{ha}^{-1}$ kezelésének átlagában ezek a visszanyerési \% arányok azonos sorrendet és közel azonos arányokat mutattak; Nagyhörcsök, 1994, a három adag átlagában: $\mathrm{Cd}(89 \%)>\mathrm{Cu}(83 \%)>\mathrm{Zn}(59 \%)>\mathrm{Se}(36 \%)>\mathrm{As}(32 \%)>\mathrm{Hg}(16 \%)$ $>\mathrm{Cr}(4 \%)$; a három helyszín átlagában: $\mathrm{Cd}(88 \%)>\mathrm{Cu}(76 \%)>\mathrm{Zn}(52 \%)>\mathrm{Se}$ $(32 \%)>\operatorname{As}(31 \%)>\mathrm{Hg}(13 \%)>\mathrm{Cr}(3 \%)$ (1. és 2. táblázat).

Annak ellenére, hogy a talajtulajdonságok függvényében a környezetbe kijutott / kijuttatott potenciálisan káros elemek igen eltérő módon viselkedhetnek, kísérleti eredményeink alapján úgy találtuk, hogy a LE-oldható elemtartalomban kifejezett és az „összes” elemtartalomban kifejezett visszanyerési százalékok egymáshoz viszonyított aránya inkább elem-, mint talajtulajdonság-függő (3. táblázat).

\section{3. táblázat}

A potenciálisan káros elemek LE-oldható, illetve „összes” elemtartalom visszanyerési százalékai egymáshoz viszonyított arányainak elemsorrendje a három kísérleti helyen beállított károselem-terheléses kísérlet szántott rétegében, a $270 \mathrm{~kg} \mathrm{ha}^{-1}$ kezelésben

\begin{tabular}{|l|c|c|c|c|c|c|c|}
\hline $\begin{array}{c}\text { Kísérleti } \\
\text { hely (1) }\end{array}$ & Cd & Cu & Zn & Se & As & Hg & Cr \\
\hline \multicolumn{7}{|c|}{ (LE visszanyerési \%) / ("összes" visszanyerési \%) arány, \% (2) } \\
\hline ÖB & - & 70 & 36 & 27 & - & - & 2 \\
\hline NH & 89 & 83 & 59 & 36 & 32 & 16 & 4 \\
\hline GYÖ & 86 & 76 & 60 & - & 30 & 9 & 2 \\
\hline Átlag (3) & 88 & 76 & 52 & 32 & 31 & 13 & 3 \\
\hline
\end{tabular}

ÖB = Örbottyán, NH = Nagyhörcsök, GYÖ = Gyöngyös

Ezt a hipotézist erősíti az a tény is, hogy a kijuttatott potenciálisan káros elemek LE visszanyerési százalék / "összes” visszanyerési százalék arányainak 
sorrendje a különböző tulajdonságú talajokon, hasonló korú károselem-terheléses tartamkísérletekben, azonos volt (3. táblázat).

Úgy találtuk, hogy a három, egymástól jelentősen eltérő tulajdonságú talajon viszonylag azonos időben, azonos mennyiségben és azonos formában kijuttatott potenciálisan káros elemeknek a LE-oldható, és "összes" (cc. $\mathrm{HNO}_{3}+\mathrm{cc} \cdot \mathrm{H}_{2} \mathrm{O}_{2}$ oldható) elemtartalomban mért visszanyerési százalék arányainak sorrendje állandó, tehát a talajtulajdonságoktól független volt (3. táblázat).

Ez alapján fogalmaztuk meg a SZABÓ-CSATHÓ-KÁDÁR-féle potenciálisan toxikus talaj-mikroelem kiterjeszthetöségi szekvens megnevezést. Feltételezésünk szerint, mivel a LE-oldható talaj potenciális károselem-tartalmak meglehetősen talajtulajdonság-függetlennek bizonyultak - az "összes" elemtartalmakkal párhuzamosan meghatározva - alkalmasak lehetnek a szennyezett talajok könnyen oldható frakciójának jellemzésére, a jogszabályokban való párhuzamos szerepeltetésére. Mint ismeretes, a hazai jogszabályokban jelenleg csupán az "összes" / pszeudoösszes elemtartalmakban kifejezett határértékek szerepelnek. Hipotézisünk szerint tehát, a SZABÓ-CSATHÓ-KÁDÁR-féle potenciálisan toxikus talajmikroelem kiterjeszthetöségi szekvens megközelítés alkalmas lehet arra, hogy a talaj könnyen oldható károselem-szennyezettségét becslö talajvizsgálati módszerek erőteljesen talajtulajdonság-függő, illetve kevésbé talajtulajdonság-függő voltára információkat nyerjünk. Természetesen ezen hipotézisünket még számos más talajtípuson, hasonló feltételekkel beállított tartamkísérletben is szükséges lenne bizonyítani.

\section{Következtetések}

Kádár Imre nehézfém-terheléses szabadföldi tartamkísérlete a világon egyedülálló lehetőséget nyújt ezen elemeknek a talaj-növény rendszerben való hatása időbeni változásának, illetve egymáshoz való összehasonlításának tanulmányozására.

Jelen dolgozatunkban a talaj cc. $\mathrm{HNO}_{3}+\mathrm{cc} \cdot \mathrm{H}_{2} \mathrm{O}_{2}$ („összes”) és a LE-oldható visszanyerési százalékok idôbeni változásainak, illetve egymáshoz viszonyított összehasonlításainak értékelésére helyeztük a hangsúlyt.

$\mathrm{Az}$ azonos só formákban, hasonló adagokkal meszes homok és savanyú barna erdőtalajon is beállított károselem-terheléses tartamkísérlet adatai lehetőséget nyújthatnak a talaj könnyen oldható elemtartalmának meghatározására kidolgozott LE-módszer kiterjeszthetőségének vizsgálatára is.

\section{Összefoglalás}

Dolgozatunkban Kádár Imre 1991 tavaszán meszes csernozjom talajon 13 potenciálisan toxikus mikro- / károselem $(\mathrm{Al}, \mathrm{As}, \mathrm{Ba}, \mathrm{Cd}, \mathrm{Cr}, \mathrm{Cu}, \mathrm{Hg}, \mathrm{Mo}, \mathrm{Ni}, \mathrm{Pb}$, Se, Sr és Zn) 0-90-270-810 $\mathrm{kg} \mathrm{ha}^{-1}$ szintjeivel beállított szabadföldi tartamkísérlete 1-20. évi talajvizsgálati-, illetve talaj visszanyerési százalék eredményeit értékeltük. 
Nehézfémterhelés hatása ... visszanyerési százalékuk alakulására... 307

A LE-oldható ( $\mathrm{NH}_{4}$-acetát+EDTA) és ,összes” (cc. $\left.\mathrm{HNO}_{3}+\mathrm{cc} \cdot \mathrm{H}_{2} \mathrm{O}_{2}\right)$ elemtartalmak aboszlút értékeinek változásai mellett figyelemmel kísértük az elemek visszanyerési százalékainak időbeni változásait is.

A kísérlet 4. évében a legnagyobb talaj LE-oldható visszanyerési százalékokat a kationos formában kiadott elemek esetében kaptunk, míg az anionos formában kijuttatottak (Se, As, Mo, Cr) az elemsorrend második felében, illetve a végén helyezkedtek el.

A kísérlet 18. évére a legtöbb elem LE módszer szerint kimutatott oldhatósága, és így visszanyerési százaléka kisebb-nagyobb mértékben csökkent. Legnagyobb csökkenéseket a $\mathrm{Sr}, \mathrm{Pb}, \mathrm{Zn}$, míg legkisebbeket a $\mathrm{Mo}, \mathrm{Cr}$ és $\mathrm{Cd}$ elemek mutattak. A tápláléklánc szennyeződése szempontjából kedvezőtlen, hogy a kijuttatott karcinogén Cd jelentős hányada maradt a könnyen oldható frakcióban, és ez a frakció a 14 év alatt is csak minimálisan csökkent a meszes csernozjom talajon.

$\mathrm{Az}$ elemek átlagában, a LE-oldható elemtartalomban mért visszanyerési százalék 1994-ben 41\%, míg 2008-ban 22\% volt. A 14 év alatt tehát az átlagos, LEoldható elemtartalomban mért visszanyerési százalék 19 abszolút \%-kal csökkent, azaz gyakorlatilag megfeleződött.

Az egyes elemek „összes” elemtartalomban a kísérlet 4. évében mért visszanyerési százalékának sorrendje a LE-oldható tartalmaknál leírtakhoz hasonlóan alakult; a legkisebb visszanyerési százalékokat itt is az anionos formában kijuttatott elemeknél kaptunk. Míg a LE-oldható tartalmaknál a $\mathrm{Hg}$, addig az „összes” elemtartalmaknál a $\mathrm{Cd}$, mint nehézfém ékelödött be az anion formában kijuttatott elemek közé.

A kísérlet 18. évében az „összes” elemtartalomban mért visszanyerési százalékok esetében a legnagyobb csökkenéseket a $\mathrm{Se}, \mathrm{Sr}, \mathrm{Pb}$, míg legkisebbeket a $\mathrm{Cd}$, Mo és Cr elemek mutattak. Az utóbbi három elem közül humán egészségügyi szempontból a Cd tekinthető a legveszélyesebbnek.

$\mathrm{Az}$ elemek átlagában, az „összes” elemtartalomban mért visszanyerési százalék 1994-ben 81\%, míg 2008-ban 49\% volt. A 14 év alatt tehát az átlagos összes elemtartalomban mért visszanyerési százalék 32 abszolút \%-kal csökkent.

A meszes csernozjom, meszes homok, és savanyú, agyagos vályog textúrájú barna erdőtalajon beállított károselem-terheléses tartamkísérlet adatainak tanúsága szerint a LE-oldható elemtartalomban kifejezett, és az „összes” elemtartalomban kifejezett visszanyerési százalékok egymáshoz viszonyított aránya inkább elem-, mint talajtulajdonság-függő.

Úgy találtuk, hogy a három, egymástól jelentősen eltérő tulajdonságú talajon viszonylag azonos időben, azonos mennyiségben és azonos formában kijuttatott potenciálisan káros elemeknek a LE-oldható elemtartalomban mért visszanyerési százalékok és "összes" (cc. $\mathrm{HNO}_{3}+\mathrm{cc} \cdot \mathrm{H}_{2} \mathrm{O}_{2}$-oldható) elemtartalomban mért visszanyerési százalékok arányainak sorrendje állandó, tehát a talajtulajdonságoktól független volt.

Ezen felismerés alapján fogalmaztuk meg a SZABÓ-CSATHÓ-KÁDÁR-féle potenciálisan toxikus talaj-mikroelem kiterjeszthetöségi szekvens megnevezést. Természetesen ezen hipotézisünket még számos más talajtípuson, hasonló feltételekkel beállított tartamkísérletben is szükséges lenne bizonyítani. 
Kulcsszavak: szabadföldi tartamkísérlet; káros mikroelem; talajszennyezés; visszanyerési százalék, kiterjeszthetőségi szekvens

\section{Köszönetnyilvánítás}

Szerzők nagy kiváltságnak tartják, hogy Prof. Dr. Kádár Imrétől a tartamkísérlet alapadatait további értékelés, szintézis céljából megkaphatták. Szerzők ezen munkájukat Prof. Dr. Kádár Imre, a cikkünk tárgyát képező, a világon egyedülálló potenciális károselem-terheléses tartamkísérlet beállítója emlékének szentelik, tiszteletük és nagyrabecsülésük jeléül.

\section{Irodalom}

ACKERFOLS, H., 1971. Mercury pollution in Sweden with special reference to conditions in the water habitat. In: III. Effects of particular pollutants. Proc. Royal Society of London. B. 177. 365-387.

AllowAY, B.J., 2013. Heavy Metals in Soils. Trace Metals and Metalloids in Soils and their Bioavailability. Springer, Dordrecht-Heidelberg-London-New York.

Bersényi, A., Fekete, S., Hullár, I., Kádár, I., Szilágyi, M., Glávits, R., KULCSÁR, M., MÉZES, M., ZÖLDÁG, L., 1999. Study of the soil-plant (carrot)animal cycle of nutritive and hazardous minerals in a rabbit model. Acta Veterinaria Hungarica. 47. 181-190.

BoLDIS, O., 1994. Magyarországi talajok toxikus nehézfémtartalma. MTESZ, 1988.V.9. Budapest (előadás anyaga). In: CSATHÓ P., 1994a. A környezet nehézfém szennyezettsége és az agrártermelés. Tematikus szakirodalmi szemle. Akaprint, Budapest.

CsATHó, P., 1994a. A környezet nehézfém szennyezettsége és az agrártermelés. Tematikus szakirodalmi szemle. Akaprint, Budapest. 176 p.

CsATHÓ, P., 1994b. Nehézfém- és egyéb toxikuselem-forgalom a talaj-növény rendszerben. Agrokémia és Talajtan. 43. 371-398.

DEBRECZENI I., IZSÁKI Z., 1989. A börgyári szennyvíziszap trágyázás hatása és utóhatása kalászos gabonákra homoktalajon. Növénytermelés. 38. 231-239.

DELL INC., 2015. Dell Software Statistica. Statistics for Windows, Version, 13.0 Round Rock, Texas: DELL INC.

Enamorado, S., Abril, J.M., Delgado, A., Más, J.L., Polvillo, O., Quintero, J.M., 2014. Implications for food safety of the uptake by tomato of 25 traceelements from a phosphogypsum amended soil from SW Spain. Journal of Hazardous Materials. 266. 122-131.

FODOR, L., 2002. Nehézfémek akkumulációja a talaj-növény rendszerben. VE Georgikon Mezőgazdaságtudományi Kar, Keszthely. $\mathrm{PhD}$ disszertáció.

FODOR L., SZABÓ, L., 2006. Chemical detection of heavy metals applied at high rates to soil. Communications in Soil Science and Plant Analysis. 37. (15-20). 2523-2530. 
GuPTA, U.C., GuPTA, S.C., 1998. Trace element toxicity relationships to crop production and livestock and human health: implications for management, Communications in Soil Science and Plant Analysis. 29. (11-14) 1491-1522.

Györi, Z., Goulding, K., Blake, L.; Prokisch, J., 1996. Changes in the heavy metal contents of soil from the Park Grass Experiment at Rothamsted Experimental Station. Fresenius Journal of Analitical Chemistry. 354. 699702.

HARTIKAINEN, H., 2005. Biogeochemistry of selenium and its impact on food chain quality and human health. Journal of Trace Elements in Medicine and Biology. 18. 309-318.

HooDA, P.S., 2010. Assessing bioavailability, risk assasmant and remediation. In: Hooda, P.S. (ed): Trace Elements in Soils. Blackwell Publishing Ltd. pp. 229266.

ISO 11466:1995. Soil quality - Extraction of trace elements soluble in aqua regia. https://www.iso.org/standard/19418.html

IZSÁKI, Z., DEBRECZENI, I., 1987. Bőrgyári szennyvíziszappal végzett trágyázás hatásának vizsgálata homoktalajon. Növénytermelés. 36. 481-489.

Juste, C., MENCH, M., 1992. Long-term application of sewage sludge and its effect on metal uptake by crops. In: Biochemistry of Trace Metals (ed. ADRIANO, D.) Lewis Publishers. Boca Raton - Ann Arbour - London - Tokyo. pp. 157-173.

KabAtA-PENDiAS, A., 2011. Trace Elements in Soils and Plants, $4^{\text {th }}$ edition. CRC Press; Taylor \& Francis. Boca Raton.

Kabata-Pendias, A., Mukherjee, A. B., 2007. Trace Elements from Soil to Human. Springer, Berlin-Heidelberg.

KÁDÁR, I., 1995a. A talaj-növény-állat-ember tápláléklánc szennyeződése elemekkel Magyarországon. KTM-MTA TAKI. Budapest.

KÁDÁR, I., 1995b. 17. Talajaink és növényeink összetétele nemzetközi összehasonlításban. In: KÁDÁR I., (szerk.) A talaj-növény-állat-ember tápláléklánc szennyeződése elemekkel Magyarországon. KTM-MTA TAKI. Budapest. pp. 298-320.

KÁDÁR, I., 1998. A szennyezett talajok vizsgálatáról. Kármentesítési kézikönyv 2. Környezetvédelmi Minisztérium. Budapest.

KÁDÁR, I., 2009. A talajszennyezés megítélése kutatói szemmel. 4. Agrokémia és Talajtan. 58. (1) 149-168.

KÁDÁR, I., 2012a. A főbb szennyező mikroelemek környezeti hatása. MTA ATK TAKI, Budapest. 360.

KÁDÁR, I., 2012b. Az örbottyáni mikroelem-terheléses kísérlet ismertetése. In: KÁDÁR I. (szerk.), A főbb szennyező mikroelemek környezeti hatása. MTA ATK TAKI, Budapest. pp. 222-316.

KÁDÁR, I., FEKETE, S., 1995. 18. Takarmányozási kísérletek eredményei. In: KÁDÁR I. (szerk.), A talaj-növény-állat-ember tápláléklánc szennyeződése elemekkel Magyarországon. KTM-MTA TAKI. Budapest. 321-371.

Kirby, J.K., McLaughlin, M.J., MA, Y.B. AJiBOYE, B. 2012. Aging effects on molybdate lability in soils. Chemosphere. 89. (7) 876-883. 
Korte, N.E., Skopp, J., Fuller, W.H., Niebla, E.E., AlsseiI, B.A., 1976. Trace element movement in soils, influence of soil physical and chemical properties. Soil Science. 122. 350-359.

Kovács, B., Prokisch, J., Györi, Z., Balla Kovács, A., Palencsár, A.J., 2000. Studies on soil sample preparation for inductively coupled plasma atomic emission spectrometry analysis. Communications in Soil Science and Plant Analysis. 31. 1949-1963.

Kumpiene, J., Giagnoni, L., Marschner, B., Denys, S., Mench, M., Adriaensen, K., VAngronsveld, J., Puschenreiter, M., Renella, G. 2017. Assessment of methods for determining bioavailability of trace elements in soils: A review. Pedosphere. 27. (3) 389-406.

LAING, G.D., 2010. Analysis and Fractionation of Trace Elements in Soils. In: HoodA, P.S. (ed): Trace Elements in Soils. Blackwell Publishing Ltd. pp. 53-80.

LAKANEN, E., ERVIÖ, R., 1971. A comparison of eight extractants for the determination of plant available microelements in soils. Acta Agralia Fennica. 123. 223-232.

LEHOCZKY, É., MARTH, P., SZABADOS, I., SzOMOLÁNYI, Á., 1998. Effect of liming on the heavy metal uptake by lettuce. Agrokémia és Talajtan. 47. (1-4) 229-234.

LISK, D.J., 1972. Trace metals in soils, plants and animals. Advances in Agronomy. 24. 267-325.

Lock, K., Waegeneers, N., Smolders, E., Criel, P., VAn EecKhout, H., \& JANSSEN, C. R. 2006. Effect of leaching and aging on the bioavailability of lead to the springtail Folsomia candida. Environ. Toxicol. Chem. 25. (8) 2006-2010.

LU, A, ZHANG, S. QIN, X. WU, W \& LIU, H. 2009. Aging effect on the mobility and bioavailability of copper in soil. Journal of Environmental Sciences. 21. (2) 173-178.

Ma, Y.B., Lombi, E., Mclaughlin, M.J., Oliver, I.W., Nolan, A.L., OORTS, K. \& SMOLDERS, E. 2013. Aging of nickel added to soils as predicted by soil $\mathrm{pH}$ and time. Chemosphere. 92. (8) 962-968.

MCKENNA, I.M, CHANEY, R.L., WILliAMS, F.M., 1993. The effects of cadmium and zinc interactions on the accumulation and tissue distribution of zinc and cadmium in lettuce and spinach. Environmental Pollution. 79. (2) 113-120.

Mikkelsen, R.L., Page, A.L., HaghniA, G.H., 1988. Effect of salinity and its composition on the accumulation of selenium by alfalfa. Plant and Soil. 107. 63-67.

MORTVEDT, J. J., 1991 Micronutrients in agriculture, $2^{\text {nd }}$ edition. SSSA Book Series No. 4. Madison, Wisc., USA

MSZ 21470-50 (2006). Környezetvédelmi talajvizsgálatok. Az összes és oldható toxikus elem, nehézfém és Cr (VI) tartalmának meghatározása. Magyar Szabványügyi Testület. Budapest. 
NÉMeth, T., SZABó, J., PÁszTor, L., BAKacsi, Zs., Ódor, L., HoRVÁth, I., FÜGEDI, U., MARTH, P., SZALAI, L., 1997. A magyarországi talajok alapterheltségi szintjének leírása. Zárójelentés. KTM - (KEV-2631/96) Projekt. MTA TAKI-MÁFI-BFNTÁ, Budapest.

PALMER, C.D., PUls, R.W., 1994. Natural Attenuation of Hexavalent Chromium in Groundwater and Soils. EPA Ground Water Issue. US EPA /540/5-94/505. pp. $1-12$.

PavlíčKovÁ, J., ZBíral, J., ČIŽMÁRovÁ, E., KubáŇ, V., 2003. Comparison of aqua regia and $\mathrm{HNO}_{3}-\mathrm{H}_{2} \mathrm{O}_{2}$ procedures for extraction of $\mathrm{Tl}$ and some other elements from soils. Analytical and Bioanalytical Chemistry. 376. (1) 118-125.

ProKisch, J., 2010. Vigyázat, méreg! Az öt legveszélyesebb mérgező fém a környezetünkben: arzén, ólom, higany, kadmium és króm(VI). Dr. Aliment Kft., Debrecen.

Reimann, C., Fabian, K., Birke, M., Demetriades, A., Matschullat, J., Schoeters I., The GEMAS Project Team., 2018. The GEMAS periodic table of agricultural soil in Europe. The Geological Surveys of Soils in Europe - European Association of Metals / EUMETAUX. http://gemas.geolba.ac.at/. June 22, 2018.

RÉKÁSI, M., FILEP, T., 2006. Effect of microelement loads on the element fractions of soil and plant uptake. Agrokémia és Talajtan 55. 213-222.

Rosenfels, R.S., CRAFTS, A.S., 1939: Arsenic fixation in relation to the sterilization of soils with sodium arsenite. Hilgardia. 12. 201-223.

SANDER, C., JACOBI, H., 1967. Methemoglobin poisoning in a 2-year old boy after eating spinach [in German]. Z. Kinderheilkd. 98. 222-226.

SCHACKLETTE, H.T., BOERNGEN, J.G., 1984. Element concentrations in soils and other surficial materials of the conterminous United States. US Geological Survey Professional Papers 1270. US Dept. Interior.

SILlANPÄÄ, M., 1982. Micronutrients and the Nutrient Status of Soils: a Global Study. FAO Soils Bulletin. No. 48. Rome.

SILlANPÄ̈̈, M., JANSSON, H., 1992. Status of cadmium, lead, cobalt and selenium in soils and plants of thirty countries. FAO Soils Bulletin. No. 65. Rome.

SIMON, L., 2014. Potentially harmful elements in agricultural soils. In: BINI, C. \& BECH, J. (eds.), PHEs, Environment and Human Health. Potentially Harmful Elements in the Environment and the Impact on Human Health. Springer, Dordrecht, Heidelberg, New York, London. pp. 85-137; pp. 142-150.

Szabó, A., Pokovai, K., RéKÁsi, M., Csathó, P., KádÁr, I., Lehoczky, É., 2015. Changes in soluble element contents in heavy metal loading field trial set up on a calcareous chernozem soil. Proceedings of the $21^{\text {st }}$ International Symposium on Analytical and Environmental Problems. University of Szeged, Department of Inorganic and Analytical Chemistry. pp. 72-75.

Szabó, A., PoKovai, K., Ragályi, P., RéKÁSI, M., SÁndor, R., BERnhardt, B., Koncz, J., Haszon, B., Kremper, R., Csathó, P., 2019a. Nehézfém- és egyéb toxikus mikroelem-terhelés tartamhatása a talaj károselem tartalmak alakulására, szabadföldi kísérletben. Acta Agronomica Óváriensis. 60. (2) Közlésre elfogadva 
Szabó, A., Pokovai, K., RagÁlyi, P., RÉKÁSi, M., SÁndor, R., Bernhardt, B., Koncz, J., KReMPer, R., CsAThÓ, P., 2019b. Nehézfém- és egyéb toxikus mikroelem-terhelés tartamhatása a főtermés mennyiségére, szabadföldi kísérletben. Agrokémia és Talajtan. 68. (2). 259-278.

TESSIER, A., CAMPBEll, P.G.C., 1988. Partitioning of trace metals in sediments. In: Kramer, J.R. Allen, H.E. (eds.). Metal Speciation: Theory, Analysis and Application. Lewis Publisher, Chelsea, MI. pp. 183-199.

ThORNTON, I., 1995. Metals in the Global Environment: Facts and Misconceptions. Ottawa, International Council on Metals and the Environment.

VÁRALlyAY, G., (szerk.) 1995. Talajvédelmi információs és monitoring rendszer I. Módszertan. FM Növényvédelmi és Agrár-környezetgazdálkodási Föosztály, Budapest.

WEST, T.S., 1981. Soil as a source of trace elements; Philosophical Transactions of the Royal Society of London. Series B. 294. 19-30.

ZEREMSKI-ŠKKORIĆ, T., SeKulić, J., RAlEV, J., KASTORI, R., 2006. Comparison of aqua regia and $\mathrm{HNO}_{3}-\mathrm{H}_{2} \mathrm{O}_{2}$ procedures for extraction of trace elements from chernozem soils. In: (eds.: SzILÁGYI, M. - SzENTMIHÁlyi, K.), Proc. Int. Symp. "Trace Elements in the Food Chain". Hungarian Academy of Sciences. Budapest, Hungary. pp. 97-101.

\title{
Investigations on the long-term effect of heavy metal and other toxic trace element load on their recovery percentages, as measured in the soil, in field trials
}

\author{
${ }^{1 *}$ A. Szabó, ${ }^{1}$ K. Pokovai, ${ }^{1}$ P. RagÁlyi, ${ }^{1}$ M. RÉKÁSI, ${ }^{2}$ R. SÁndor, ${ }^{1}$ B. Bernhardt, \\ ${ }^{1}$ J. KONCZ, ${ }^{3}$ R. KREMPER, ${ }^{1}$ P. CSATHÓ \\ ${ }^{1}$ Institute for Soil Sciences and Agricultural Chemistry, \\ Centre for Agricultural Research, Budapest \\ ${ }^{2}$ Agricultural Institute, Centre for Agricultural Research, Martonvásár \\ ${ }^{3}$ University of Debrecen, Faculty of Agricultural and Food Sciences and Environmental \\ Management, Institute of Agricultural Chemistry and Soil Science, Debrecen
}

\section{Summary}

So that to study the potentially harmful trace element load, a long-term field experiment was established in spring, 1991 on a calcareous chernozem soil, with 13 elements (Al, As, Ba, Cd, Cr, Cu, Hg, Mo, Ni, Pb, Se, Sr, Zn), with 0-90-270-810 $\mathrm{kg} \mathrm{ha}^{-1}$ doses, by Prof. Dr. Imre Kádár. The soil Lakanen-Erviö- (LE-) $\left(\mathrm{NH}_{4}{ }^{-}\right.$ acetate+EDTA) soluble and ,total” (cc. $\mathrm{HNO}_{3}+\mathrm{cc} . \mathrm{H}_{2} \mathrm{O}_{2}$ ) element contents as well as soil recovery percentages were investigated in the 1 to 20 years periods of the trial.

In the $4^{\text {th }}$ year of the trial, there were higher LE recovery percentages in the elements applied in cationic forms, while those applied in anionic forms (Se, As, $\mathrm{Mo}, \mathrm{Cr}$ ) were situated in the second half, or even at the end of the element sequence. 
In the $18^{\text {th }}$ year of the trial, there were further decreases in the LE recovery percentages. Highest decreases were detected at $\mathrm{Sr}, \mathrm{Pb}$, and $\mathrm{Zn}$, while, smallest ones at $\mathrm{Mo}, \mathrm{Cr}$ and $\mathrm{Cd}$ elements. From the point of view of contamination of the food chain, it is highly unfavourable that a high proportion of $\mathrm{Cd}$ applied remained in easily soluble form, and this fraction diminished only slightly after 14 years elapsed.

In the average of the elements, LE recovey percentages were $41 \%$ in 1994 , while $22 \%$ in 2008 . The ,aging effects" of these 14 years resulted in average 19 absolute percentage decrease in LE recovery percentage, i.e., it was almost halved.

In the $4^{\text {th }}$ year of the trial, ,total" recovery percentages showed similar sequences to that of LE recovery percentages. Lowest „total” recovery percentages were detected in the elements applied in in anionic forms. While, in case of LE recovery percentages, $\mathrm{Hg}$, and, at ,total” recovery percentages, $\mathrm{Cd}$ as heavy metals were wedged in the elements applied in anionic forms.

In the $18^{\text {th }}$ year of the trial, $\mathrm{Se}, \mathrm{Sr}$, and $\mathrm{Pb}$ showed highest decreases in „total" recovery percentages, while, $\mathrm{Cd}$, Mo, and $\mathrm{Cr}$ the lowest ones, as compared to the recovery percentages in the $4^{\text {th }}$ year. Among the latter elements, from the point of view of human health risks, it is $\mathrm{Cd}$ that is considered as the most dangerous one.

In the average of the elements, „total" recovery percentages were $81 \%$ in 1994 , while $49 \%$ in 2008. The ,aging effects" of these 14 years resulted in average 32 absolute percentage decrease in ,total" recovery percentage.

According to the results, obtained in the long-term field trials, set up in a calcareous chernozem, in a calcareous sandy soil, and in an acid brown forest soil with clay loam soil texture, ratio of LE recovery percentages to „total” recovery percentages depended rather on the elements than on soil properties.

It was found that the sequence of the ratio of LE recovery percentages to „total" recovery percentages obtained in the three soils with different soil properties was constant, i.e., independent of soil properties. The harmful element forms, doses, and the time elapsed since application were similar in the three long-term field experiments.

Based on this finding, the expandibility sequence of soil potentially toxic trace elements, according to SZABÓ-CSATHÓ-KÁDÁR was formulated. Obviously, this hypothesis must be proven with the results of other longh-term field trials, set up under differend soil conditions.

Keywords: long-term field trial; harmful trace elements; soil contamination; recovery percentage; expandibility sequence 


\section{Tables and figures}

Figure 1. Recovery percentages of LE- soluble potentially toxic trace elements in 1994 and 2008 in the ploughed soil layer. Calcareous Chernozem, Nagyhörcsök. Statistically significant differences within a year are marked by lower case letters, whereas differences between years by upper case letters. (1) Recovery percentage

Figure 2. Recovery percentages of "total" potentially toxic trace elements in 1994 and 2008 in the ploughed soil layer. Calcareous Chernozem, Nagyhörcsök. Statistically significant differences within a year are marked by lower case letters, whereas differences between years by upper case letters. (1) Recovery percentage

Table 1. Ratios of recovery percentages of trace elements in soil as functions of extraction method and time elapsed since application. Calcareous Chernozem, Nagyhörcsök, 1994 and 2008. (1) Elements; (2) LE-soluble element ratio; (3) „Total” element ratio; (4) LE-soluble / „Total” element ratio 1994 (\%); (5) LE-soluble / „Total” element ratio 2008 (\%); (6) Recovery percentage; (7) Mean

Table 2. Recovery percentages of potentially toxic trace elements, as measured by the LE-soluble, and by the ,total" soil test methods, as well as their ratios, in the ploughed soil layer, obtained in the three toxic trace element loads longterm field trials, in the plought layer, in the $270 \mathrm{~kg} \mathrm{ha}^{-1}$ treatments. (1) Element; (2) LE recovery percentage \%; (3) ,total” recovery percentage \%; (4) (LE recovery percentage) to "(total" recovery percentage) ratio, \%; (5) ÖB $\left(6^{\text {th }}\right.$ year); (6) NH (4 ${ }^{\text {th }}$ year); (7) GYÖ ( $2^{\text {nd }}$ year); (8) Mean

Table 3. Recovery percentage ratios of the potentially toxic trace elements, as measured by the LE-soluble, and by the "total" soil test methods, obtained in the three long-term field trials, in the ploughed soil layer, in the $270 \mathrm{~kg} \mathrm{ha}^{-1}$ dose treatments. (1) Experimental sites; (2) (LE recovery percentage) to "(total" recovery percentage) ratio, \%; (3) Mean

Open Access nyilatkozat: A cikk a Creative Commons Attribution 4.0 International License (https://creativecommons.org/licenses/by/4.0) feltételei szerint publikált Open Access közlemény, melynek szellemében a cikk bármilyen médiumban szabadon felhasználható, megosztható és újraközölhető, feltéve, hogy az eredeti szerző és a közlés helye, illetve a CC License linkje és az esetlegesen végrehajtott módosítások feltüntetésre kerülnek. (SID_1) 